\title{
THE RISK OF HYPERTENSION ON THE INCIDENCE OF CORONARY HEART DISEASE IN URBAN AND RURAL COMMUNITIES INDONESIA (LONGITUDINAL ANALYSIS OF IFLS 2007-2014)
}

\author{
Riska Desti Ayu, Nurhayati Adnan \\ Public Health Faculty Universitas Indonesia, Street. Margonda Raya, Depok, West Java 16424, Indonesia
}

\begin{abstract}
ABSTACT
Coronary heart disease (CHD) is a leading cause of death globally with a mortality rate of nearly 17.5 million annually. Hypertension accounts for $31 \%$ of all deaths from cardiovascular disease. High blood pressure (hypertension) is one of the main risk factors for CHD which is a serious problem that needs to be addressed in Indonesia and the world. The purpose of this study was to assess the risk of hypertension in the incidence of coronary heart disease in urban and rural communities in Indonesia. This research is using a retrospective cohort study design. The data used are secondary data from the Indonesian Family Life Survey (IFLS-4 and IFLS-5 data for 2007-2014) with a total sample of 22,656 population respondents aged $\geq 18$ years. The Cox regression multivariable method was used to estimate the risk of $C H D(R R)$ and its $95 \%$ confidence interval. Multivariate analysis results after adjusting for cholesterol history showed that respondents with hypertension in urban communities were at 1.36 times more risk $(95 \% \mathrm{CI}$; 1.05-1.77) had coronary heart disease compared to respondents who were not hypertensive/normal in Indonesia 2007-2014. Whereas in rural communities, there was no significant relationship between hypertension and CHD with RR values of $1.07(95 \% \mathrm{CI}=0.78-1.48)$.
\end{abstract}

Keywords: Hypertension, Coronary Heart Disease, Urban and Rural, IFLS

\begin{abstract}
ABSTRAK
Penyakit jantung koroner (PJK) merupakan penyebab utama kematian secara global dengan angka kematian hampir 17,5 juta setiap tahunnya. Hipertensi menyumbang $31 \%$ dari semua kematian akibat cardiovascular disease. Tekanan darah tinggi (hipertensi) adalah salah satu faktor risiko utama PJK yang menjadi masalah serius yang perlu ditangani di Indonesia maupun dunia. Tujuan penelitian ini adalah untuk menilai risiko hipertensi terhadap kejadian penyakit jantung koroner pada masyarakat perkotaan dan pedesaan di Indonesia. Penelitian menggunakan desain studi kohort retrospektif. Data yang digunakan yaitu data sekunder Indonesian Family Life Survey (Data IFLS-4 dan IFLS-5 tahun 2007-2014) dengan total sampel 22.656 responden penduduk yang berusia $\geq 18$ tahun. Analisis data dengan cox regression dan besar risiko dinyatakan dalam risk rasio (RR) dengan confidence interval (CI) $95 \%$. Data dianalisis menggunakan software pengolah data. Hasil analisis multivariat setelah dikontrol berdasarkan riwayat kolesterol didapatkan bahwa pada masyarakat perkotaan, hipertensi 1.30 kali $(95 \% \mathrm{CI}=1.00-1.68)$ lebih berisiko mengalami PJK dibandingkan dengan tidak hipertensi, sedangkan pada masyarakat pedesaan, tidak ada hubungan antara hipertensi dan PJK dengan nilai RR 1.07 (95\% CI $=0.78-1.48)$.
\end{abstract}

Kata Kunci: Hipertensi, Penyakit Jantung Koroner, Perkotaan dan Pedesaan, IFLS

Correspondence Address: Riska Desti Ayu, Public Health Faculty Universitas Indonesia, Street. Margonda Raya, Depok, West Java 16424, Indonesia, E-mail : riskadestiayu@gmail.com 


\section{Introduction}

Coronary heart disease (CHD) is the biggest cause of death in developed countries and is one of the main causes of the burden of disease in developing countries. ${ }^{1}$ According to the World Health Organization (WHO) that an estimated 17.9 million people died of cardiovascular disease in 2016 , representing $31 \%$ of all global deaths. Of these deaths, $85 \%$ are caused by heart attacks and strokes. More than three-quarters of deaths from cardiovascular disease occur in low and middleincome countries. ${ }^{2}$

Based on the Global Burden of Disease data in 2010 that deaths due to CHD between 1990 and 2010 in Southeast Asia increased to 77.7\% ranked third after East and South Asia. Deaths from CHD in China, India, sub-Saharan Africa, Latin America, and the Middle East are expected to increase from 9 million to 19 million in 1990 to $2020 .^{3}$ In Indonesia, the burden of noncommunicable diseases (NCD) remains a major public health problem. One of the noncommunicable diseases that cause death and disability is $\mathrm{CHD} .{ }^{4} \mathrm{CHD}$ in Indonesia continues to increase, according to Riskesdas in 2018, the prevalence of heart disease based on a doctor's diagnosis that is $1.5 \%$ has increased compared to the results of Riskesdas 2013 which is $0.5 \% .5,6$ Based on age groups, the prevalence of heart disease has increased along with the increasingly increasing age, namely respondents aged $15-24$ years $(0.7 \%)$, ages $25-34$ years $(0.8 \%)$, ages $35-44$ years $(1.3 \%)$, ages $45-54$ years $(2.4 \%)$, ages $55-64$ years (3.9\%), age $65-74$ years $(4.6 \%)$, age $75+$ (4.7\%). Based on residential groups, the prevalence of heart disease in urban areas $(1.6 \%)$ is higher than in rural areas $(1.3 \%){ }^{5}$ One of the risk factor is unhealthier lifestyles among urban communities. $^{7}$

Many factors can affect the occurrence of CHD. Modifiable factors such as physical activity, tobacco use, diet, "bad fat" in the blood, hypertension, and obesity; while non-modifiable risk factors include the patient's family history, the presence or absence of diabetes mellitus, and demographic characteristics such as age, sex, ethnicity, and socioeconomic status. ${ }^{8}$

Hypertension is an important risk factor Hypertension accounts for $31 \%$ of all deaths from cardiovascular disease. In 2012, around 17.5 million people died and were expected to increase to 1.56 billion adults with hypertension by 2025 . High blood pressure (hypertension) is a major risk factor for chronic heart disease, stroke, and coronary heart disease. Increased blood pressure (BP) is positively correlated with the risk of stroke and coronary heart disease. In addition to coronary heart disease and stroke, complications include heart failure, peripheral vascular disease, kidney disorders, retinal bleeding, and vision problems..$^{9,10}$

CHD is assumed to be the proportion of "epidemics" in many other developing countries. The prevalence rate can be estimated from several studies over the past few decades ranging from 
$1.6 \%$ to $7.4 \%$ in rural populations and $1 \%$ to $13.2 \%$ in urban populations. Although this disease is more prevalent in urban populations, this disease is increasing in rural populations in terms of absolute numbers. ${ }^{11}$

In India, the prevalence of hypertension has increased about 30 times among the urban dwellers and about ten times in the rural communities. The prevalence of hipertension differs between urban and rural communities, being higher in urban areas. ${ }^{12}$ In China, the difference in the relative prevalence of hypertension in urban and rural areas has decreased, especially in the northern regions. ${ }^{13,14}$

Based on the description, we want to examine the risk of hypertension on the incidence of CHD in urban and rural communities in Indonesia using the longitudinal data of IFLS-4 and IFLS5 in 2007-2014.

\section{Method}

This type of observational analytic study uses a retrospective cohort design looking at hypertension for the incidence of coronary heart disease. This study uses secondary data from the Indonesian Family Life Survey (IFLS) longitudinal study with characteristics of panel data that can be downloaded on the web https://www.rand.org/. ${ }^{15}$ IFLS-4 data (2007) and IFLS-5 (2014) in this study were collected from direct interviews to respondents used questionnaires and direct health measurements. At the same time respondents of IFLS-4 and IFLS- 5 before being interviewed and examined are asked to fill out the Informed Consent sheet. The confidentiality of the respondent's identity is ensured by using a code number. Ethical approval was obtained from the ethics committee of research and community service at the Indonesian University.

At the beginning of observations in 2007, those with coronary heart disease (CHD) were excluded from the study. The measurement of hypertension was carried out in 2007 using IFLS-4 data in the population aged $\geq 18$ years, then followed up by the same individual in the 2014 IFLS- 5 data related to the status of coronary heart disease. Secondary data used are secondary data from the Indonesian Family Life Survey 2007-2014 (IFLS-4 \& IFLS-5).

Indonesian Family Life Survey (IFLS) data is a continuing health survey that began in 1993 with the next four rounds of data collection with a sample representing $83 \%$ of the Indonesian population $(1997 / 1998 ; 2000 ; 2007 / 2008 ; 2014 / 2015)$. The original sampling framework is based on households from 13 provinces in Indonesia namely North Sumatra, West Sumatra, Riau, Jambi, Riau Islands, Bangka Belitung, South Sumatra, Lampung, all provinces in Java, Bali, NTB, all provinces in Kalimantan, Sulawesi South and West Sulawesi with a representation of around 83\% of Indonesia's population. ${ }^{15}$ 
The dependent variable (outcome) of the study is coronary heart disease (CHD). CHD is defined as respondents diagnosed with coronary heart disease by health workers (Doctor/Paramedic/Nurse/Midwife) in accordance with the IFLS-5 questionnaire (2014) Book IIIB Section CD (Chronic Conditions). The independent variable (exposure) of the study was hypertension. Hypertension is defined as the result of measuring average blood pressure in 2 measurements according to the IFLS-4 questionnaire (2007) US Book (Health Measurement). Classification of hypertension if blood pressure $\geq 140 / 90 \mathrm{mmHg}$ and not hypertension/normal if blood pressure $<140 / 90 \mathrm{mmHg}{ }^{16,17}$ The covariate variables were age, sex, education, obesity, smoking, cholesterol history, physical activity, history of diabetes mellitus, and occupation. Data analysis was performed using data processing software. Link analysis between independent and dependent variables uses multivariate analysis at cox regression, and for major risk ratio with $\mathrm{RR}$ and $\mathrm{CI}$ (confidence interval) by $95 \%$.

The population in this study was the population aged $\geq 18$ in Indonesia in 2007 (IFLS-4) which was then longitudinally observed until 2014 (IFLS-5). The target population in this study is the population aged $\geq 18$ years in Indonesia in 2007 . The source population in this study is the population age $\geq 18$ years in Indonesia who were respondents in IFLS-4 in 2007. The Eligible population in this study were respondents who experienced the disease of coronary heart disease (CHD) at the beginning of the study was excluded.

The measurement of hypertension was carried out in 2007 using data of population aged $\geq 18$ years in Indonesia who were respondents in IFLS-4 in 2007 who met the inclusion and exclusion criteria. The sample in this study was residents aged $\geq 18$ years in Indonesia who were respondents in IFLS-4 (2007) who were then interviewed again at IFLS-5 (2014) who had complete data in accordance with the variables to be studied. Sampling was taken by total sampling, which is an overall sampling that meets the study inclusion and exclusion criteria.

The flow of sampling in this study are as below on chart 1 shows that in 2007 (IFLS-4) there were 26.737 respondents aged $\geq 18$ years, then followed up in 2014 (IFLS-5) so that a sample that met the inclusion and exclusion criteria was 22.656 respondents. In urban communities, the number of samples was 13.211 respondents, while in rural communities, there were 9.445 respondents. The inclusion criteria in this study were the population aged $\geq 18$ years in 2007 (IFLS-5) and had blood measured at least 2 times. Blood pressure used is the average blood pressure from the first measurement and the second measurement. While the exclusion criteria in this study were respondents with coronary heart disease (CHD) in 2007 (IFLS-4), missing data from 2007 to 2014, and if the respondent could not be followed (loss to follow up) until 2014 (IFLS-5). 
Ayu et al. / Jurnal Ilmu Kesehatan Masyarakat, July 2020, 11 (2):170- 18

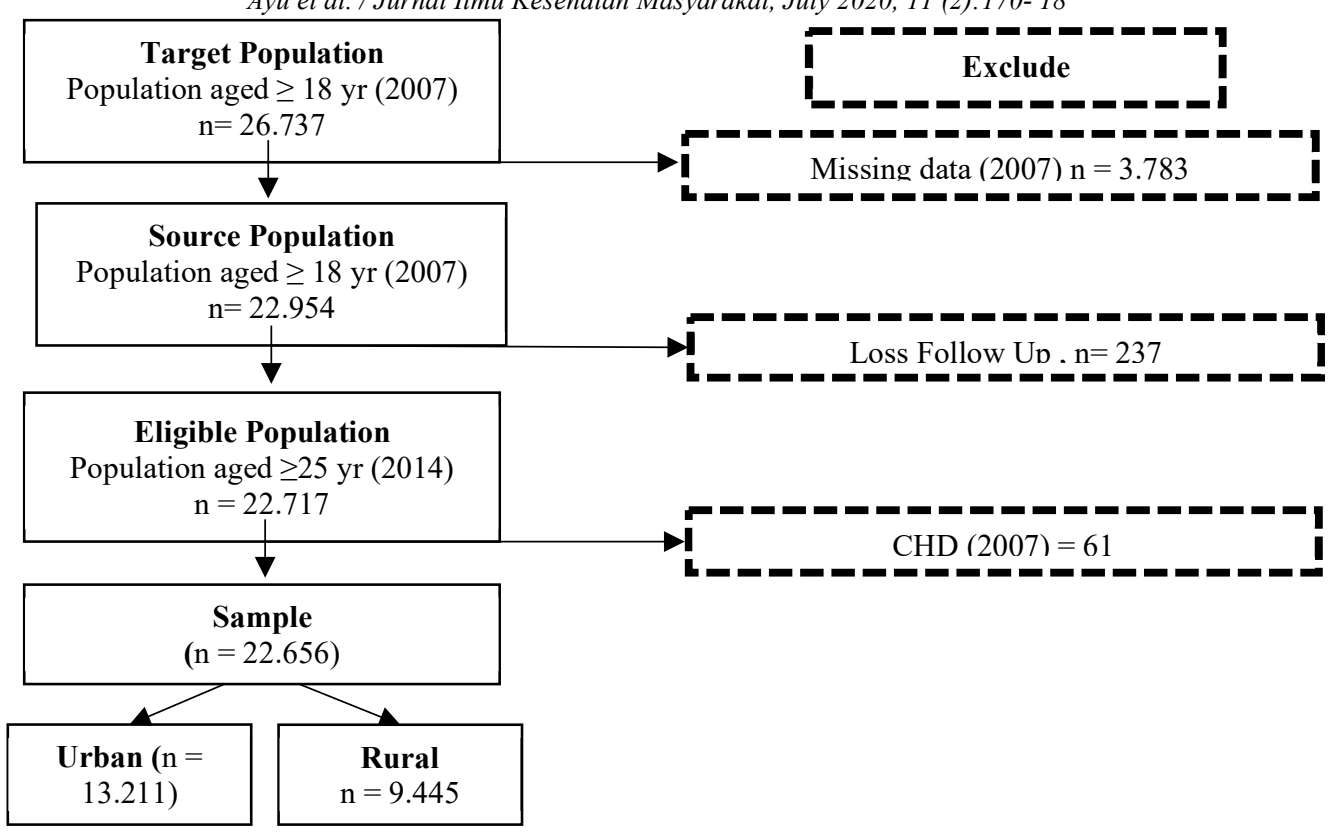

\section{Results}

Chart 1. Sampling Flow

Table 1 is a description of the characteristics of respondents from several variables in the study

Table 1. Distribution of Characteristics of Risk Factors for Coronary Heart Disease in Urban and Rural Areas Indonesian 2007-2014

\begin{tabular}{|c|c|c|c|c|c|c|}
\hline \multirow[t]{2}{*}{ Characteristic } & \multicolumn{3}{|c|}{$\begin{array}{c}\text { Urban } \\
\text { CHD }\end{array}$} & \multicolumn{3}{|c|}{$\begin{array}{l}\text { Rural } \\
\text { CHD }\end{array}$} \\
\hline & Yes & No & Total & Yes & No & Total \\
\hline \multicolumn{7}{|l|}{ Hypertension } \\
\hline Yes & $138(2.09 \%)$ & 6,472 (97.91\%) & 6,610 & $79(1.70 \%)$ & 4,563 (98.30\%) & 4,642 \\
\hline No & $97(1.74 \%)$ & $6,504(98.53 \%)$ & 6,601 & $72(1.50 \%)$ & $4,731(98,50 \%)$ & 4,803 \\
\hline \multicolumn{7}{|l|}{ Age } \\
\hline$\geq 40$ years & $161(2.62 \%)$ & $5,973(97.38 \%)$ & 6,134 & $110(2.40 \%)$ & $4,479(97.60 \%)$ & 4,589 \\
\hline$<40$ years & $74(1.05 \%)$ & $7,003(98.95 \%)$ & 7,077 & $41(0.84 \%)$ & $4,815(99.16 \%)$ & 4,856 \\
\hline \multicolumn{7}{|l|}{ Sex } \\
\hline Women & $144(2.03 \%)$ & 6,937 (97.97\%) & 7,081 & $95(1.86 \%)$ & $5,006(98.14 \%)$ & 5,101 \\
\hline Men & $91(1.48 \%)$ & $6,039(98.52 \%)$ & 6,130 & $56(1.29 \%)$ & $4,288(98.71 \%)$ & 4,344 \\
\hline \multicolumn{7}{|l|}{ Education } \\
\hline$\leq$ Junior High School & $117(1.80 \%)$ & $6,395(98.20 \%)$ & 6,512 & $116(1.66 \%)$ & $6,860(98.34 \%)$ & 6,976 \\
\hline$\geq$ Senior High School & $118(1.76 \%)$ & $6,581(98.24 \%)$ & 6,699 & $35 \quad(1.42 \%)$ & $2,434(98.58 \%)$ & 2,469 \\
\hline \multicolumn{7}{|l|}{ Obesity } \\
\hline Yes $\left(\geq 27 \mathrm{~kg} / \mathrm{m}^{2}\right)$ & $81(2.47 \%)$ & $3,203(97.53 \%)$ & 3,284 & $33(1.97 \%)$ & $1,638(98.03 \%)$ & 1,671 \\
\hline No $\left(<27 \mathrm{~kg} / \mathrm{m}^{2}\right)$ & $152(1.54 \%)$ & $9,730(98.46 \%)$ & 9,882 & $118(1.52 \%)$ & $7,630(98.48 \%)$ & 7,748 \\
\hline \multicolumn{7}{|l|}{ Smoking } \\
\hline Yes & $79(1.63 \%)$ & 4,758 (98.37\%) & 4,837 & $54(1.42 \%)$ & $3,760(98.58 \%)$ & 3,814 \\
\hline No & $156(1.86 \%)$ & $8,218(98.14 \%)$ & 8,374 & $97(1.72 \%)$ & $5,534(98.28 \%)$ & 6,631 \\
\hline \multicolumn{7}{|l|}{ Cholesterol History } \\
\hline Yes & $41(4.83 \%)$ & 807 (95.17\%) & 848 & $32(11.43 \%)$ & $248(88.57 \%)$ & 280 \\
\hline No & $194(1.57 \%)$ & $12,169(98.43 \%)$ & 12,363 & $119(1.30 \%)$ & $9,046(98.70 \%)$ & 9,165 \\
\hline \multicolumn{7}{|l|}{ Physical Activity } \\
\hline Lack & $86(1.71 \%)$ & 4,936 (98.29\%) & 5,022 & $67(2.02 \%)$ & $3,256(97.98 \%)$ & 3,323 \\
\hline Enough & $149(1.82 \%)$ & $8,040(98.18 \%)$ & 8,189 & $84(1.37 \%)$ & $6,038(98.63 \%)$ & 6,122 \\
\hline \multicolumn{7}{|l|}{ DM History } \\
\hline Yes & $25(5.58 \%)$ & $423(94.42 \%)$ & 448 & $12(8.05 \%)$ & 137 (91.95\%) & 149 \\
\hline No & $210(1.65 \%)$ & $12,553(98.35 \%)$ & 12,763 & $139(1.50 \%)$ & $9,157(98.50 \%)$ & 9,296 \\
\hline \multicolumn{7}{|l|}{ Occupation } \\
\hline No & $91(2.51 \%)$ & 3,534 (97.49\%) & 3,625 & $52(2.43 \%)$ & $2,092(97.57 \%)$ & 2,144 \\
\hline Yes & $144(1.50 \%)$ & $9,442(98.50 \%)$ & 9,586 & $99(1.36 \%)$ & $7,202(98.64 \%)$ & 7,301 \\
\hline
\end{tabular}


There are 22,656 samples were observed, the proportion of CHD in hypertension respondents in urban communities in Indonesia 2007-2014 (2.09\%) is higher than in rural communities in Indonesia 2007-2014 (1.70\%). The proportion of CHD among respondents aged $\geq$ 40 years in the urban communities in Indonesia 2007-2014 (2.62\%) was higher than in rural communities in Indonesia 2007-2014 (2.40\%). The proportion of CHD among women respondents in the urban communities in Indonesia 2007-2014 (2.03\%) was higher than in rural communities in Indonesia 2007-2014 (1.86\%). The proportion of CHD in respondents with $\leq$ JHS education in urban communities in Indonesia 2007-2014 (1.80\%) is higher than in rural communities in Indonesia 2007-2014 (1.66\%). The proportion of CHD in obese respondents in urban communities in Indonesia 2007-2014 (2.47\%) is higher than in rural communities in Indonesia 2007-2014 (1.97\%). The proportion of CHD among respondents smoking in urban communities in Indonesia $2007-2014(1.63 \%)$ is higher than in rural communities in Indonesia 2007-2014 (1.42\%). The proportion of CHD among respondents who have a history of cholesterol in rural communities in Indonesia 2007-2014 (11.43\%) is higher than in urban communities in Indonesia 2007-2014 (4.83\%). The proportion of CHD among respondents who lack physical activity in rural communities in Indonesia 2007-2014 (2.02\%) is higher than in urban communities in Indonesia 2007-2014 (1.71\%). The proportion of CHD among respondents who have a history of DM in rural communities in Indonesia 2007-2014 (8.05\%) is higher than in urban communities in Indonesia 2007-2014 (5.58\%). The proportion of CHD among respondents who did not occupation in urban communities in Indonesia 2007-2014 (2.51\%) was higher than in rural communities in Indonesia $2007-2014(2.43 \%)$.

Table 2. Analysis of Stratification Relationship Hypertension with Coronary Heart Disease in Urban and Rural Areas Indonesian 2007-2014

\begin{tabular}{|c|c|c|c|c|c|}
\hline \multirow{2}{*}{ Factors } & \multirow{2}{*}{ Category } & \multirow{2}{*}{$\mathbf{R R}$} & Urban & \multirow{2}{*}{$\mathbf{R R}$} & Rural \\
\hline & & & $95 \%$ CI & & $95 \% \mathrm{CI}$ \\
\hline \multirow[t]{2}{*}{ Age } & $\geq 40$ years & 1.56 & $1.13-2.14$ & 1.21 & $0.84-1.76$ \\
\hline & $<40$ years & 1.03 & $0.66-1.63$ & 1.04 & $0.56-1.91$ \\
\hline \multirow[t]{2}{*}{ Sex } & Women & 1.28 & $0.92-1.77$ & 0.97 & $0.65-1.44$ \\
\hline & Men & 1.73 & $1.13-2.66$ & 1.49 & $0.88-2.54$ \\
\hline \multirow[t]{2}{*}{ Education } & $\leq$ Junior High School & 1.36 & $0.94-1.96$ & 1.11 & $0.78-1.60$ \\
\hline & $\geq$ Senior High School & 1.48 & $1.03-2.13$ & 1.19 & $0.62-2.31$ \\
\hline \multirow[t]{2}{*}{ Obesity } & Yes $\left(\geq 27 \mathrm{~kg} / \mathrm{m}^{2}\right)$ & 1.42 & $0.91-2.22$ & 1.61 & $0.79-3.30$ \\
\hline & No $\left(<27 \mathrm{~kg} / \mathrm{m}^{2}\right)$ & 1.38 & $1.01-1.90$ & 1.02 & $0.71-1.46$ \\
\hline \multirow[t]{2}{*}{ Cholesterol History } & Cholesterol & 1.06 & $0.58-1.96$ & 1.45 & $0.73-2.90$ \\
\hline & Normal & 1.43 & $1.08-1.90$ & 0.99 & $0.69-1.42$ \\
\hline \multirow[t]{2}{*}{ Physical Activity } & No & 1.81 & $1.16-2.81$ & 1.42 & $0.88-2.29$ \\
\hline & Yes & 1.25 & $0.90-1.71$ & 0.95 & $0.62-1.45$ \\
\hline \multirow[t]{2}{*}{ History of DM } & DM & 1.56 & $0.66-3.65$ & 1.35 & $0.42-4.28$ \\
\hline & Normal & 1.35 & $1.03-1.78$ & 1.09 & $0.78-1.51$ \\
\hline \multirow[t]{2}{*}{ Occupation } & No & 2.50 & $1.57-3.96$ & 1.31 & $0.75-2.27$ \\
\hline & Yes & 1.01 & $0.73-1.40$ & 1.00 & $0.68-1.48$ \\
\hline
\end{tabular}


Based on table 2, analysis of stratification by age, in urban areas where respondents with age $<40$ years with hypertension risk to CHD is $1.03(95 \% \mathrm{CI}=0.66-1.63)$ meanwhile, aged $\geq 40$ years with hypertension have a risk of $1.56(95 \% \mathrm{CI}=1.13-2.14)$ times of CHD. In rural areas where respondents with age $<40$ years with hypertension risk to $\mathrm{CHD}$ is 1.04 (95\% $\mathrm{CI}=0.56-1.91$ ), meanwhile aged $\geq 40$ years with hypertension have a risk of $1.21(95 \% \mathrm{CI}=0.84-1.76)$ times of CHD.

Based on stratification analysis by sex, in urban areas where respondents men with hypertension risk to CHD is 1.03 (95\% CI $=1.13-2.66)$ meanwhile, women with hypertension have a risk of $1.28(95 \% \mathrm{CI}=0.92-1.77)$ times of CHD. In rural areas where respondents women with hypertension risk to $\mathrm{CHD}$ is $0.97(95 \% \mathrm{CI}=0.65-1.44)$ meanwhile, men with hypertension have a risk of $1.49(95 \% \mathrm{CI}=0.88-2.54)$ times of CHD.

Based on stratification analysis by education, in urban areas where respondents $\leq \mathrm{JHS}$ education with hypertension have a risk of $1.36(95 \% \mathrm{CI}=0.94-1.96)$ times of CHD meanwhile, $\geq$ SHS education with hypertension have a risk of $1.48(95 \% \mathrm{CI}=1.03-2.13)$ times of CHD. In rural areas where respondents $\leq \mathrm{JHS}$ education with hypertension risk to $\mathrm{CHD}$ is $1.11(95 \% \mathrm{CI}=0.78$ $1.60)$, meanwhile in $\geq$ SHS education with hypertension risk to CHD is $1.19(95 \% \mathrm{CI}=0.62-2.31)$.

Based on stratification analysis by obesity, in urban areas where obese respondents with hypertension have a risk of $1.42(95 \% \mathrm{CI}=0.91-2.22)$ times of CHD, meanwhile non-obese with hypertension have a risk of 1.38 (95\% CI $=1.01-1.90)$ times of CHD. In rural areas where respondents obese with hypertension have a risk of 1.61 (95\% CI $=0.79-3.30)$ time of CHD meanwhile, non-obese with hypertension risk to $\mathrm{CHD}$ is $1.02(95 \% \mathrm{CI}=0.71-1.46)$.

Based on stratification analysis by cholesterol history, in urban areas where respondents with cholesterol history with hypertension risk to CHD are 1.06 (95\% CI $=0.58-1.96)$ meanwhile, no cholesterol history with hypertension have a risk of $1.43(95 \% \mathrm{CI}=1.08-1.90)$ times of CHD. In rural areas where respondents' cholesterol history with hypertension has a risk of $1.43(95 \% \mathrm{CI}=$ 1.08-1.90) time of CHD meanwhile, no cholesterol history with hypertension risk to CHD is 0.99 $(95 \% \mathrm{CI}=0.69-1.42)$.

Based on stratification analysis by physical activity, in urban areas where respondents with lack physical activity with hypertension have a risk of $1.81(95 \% \mathrm{CI}=1.16-2.81)$ times of CHD meanwhile, enough physical activity with hypertension have a risk of $1.25(95 \% \mathrm{CI}=0.90-1.71)$ times of CHD. In rural areas where respondents with a lack of physical activity with hypertension have a risk of $1.42(95 \% \mathrm{CI}=0.88-2.29)$ time of CHD meanwhile, enough physical activity with hypertension risk to $\mathrm{CHD}$ is $0.95(95 \% \mathrm{CI}=0.62-1.45)$.

Based on stratification analysis by DM history, in urban areas where respondents with DM history with hypertension have a risk of $1.56(95 \% \mathrm{CI}=0.66-3.65)$ time of CHD meanwhile, no 
DM history with hypertension have a risk of $1.35(95 \% \mathrm{CI}=1.03-1.78)$ times of CHD. In rural areas where respondents DM history with hypertension have a risk of $1.35(95 \% \mathrm{CI}=0.42-4.28)$ time of CHD meanwhile, no DM history with hypertension risk to $\mathrm{CHD}$ is $1.09(95 \% \mathrm{CI}=0.78$ $1.51)$.

Based on stratification analysis by occupational, in urban areas where respondents do not occupation with hypertension have a risk of $2.50(95 \% \mathrm{CI}=1.57-3.96)$ time of CHD meanwhile, occupation with hypertension risk of CHD is 1.01 (95\% CI $=0.73-1.40)$. In rural areas where respondents do not occupation with hypertension have a risk of $1.31(95 \% \mathrm{CI}=0.75-2.27)$ time of $\mathrm{CHD}$, meanwhile occupation with hypertension risk to CHD is $1.02(95 \% \mathrm{CI}=0.71-1.46)$.

Tabel 3. Final Model Multivariate Analysis of the Risk of Hypertension in the incidence of Coronary Heart Disease in Urban and Rural Communities

Indonesia 2007-2014

\begin{tabular}{lllllll}
\hline & \multicolumn{3}{c}{ Urban } & \multicolumn{2}{c}{ Rural } \\
\hline Variable & RR & $\mathbf{9 5 \%}$ CI & Pvalue & RR & $\mathbf{9 5 \% ~ C I ~}$ & Pvalue \\
\hline Hypertension* & 1 & - & - & 1 & - & - \\
Normal & 1.36 & $1.05-1.77$ & 0.020 & 1.07 & $0.78-1.48$ & 0.669 \\
Hypertension & & &
\end{tabular}

Note: *adjusted by cholesterol history

Based on table 3 the final model of multivariate analysis with cox regression after controlling for confounding variables, it was found that respondents who had hypertension in urban communities were at 1.36 times more risk $(95 \% \mathrm{CI}=1.05-1.77)$ had coronary heart disease compared to respondents who were not hypertensive/normal in Indonesia 2007-2014. Whereas in rural communities, there was no significant relationship between hypertension and CHD with RR values of $1.07(95 \% \mathrm{CI}=0.78-1.48)$.

\section{Discussion}

The study was based on the Indonesian Family Life Survey (IFLS) which was a longitudinal study with a nearly $83 \%$ of Indonesian-scattered Indonesians in 13 provinces, where the data collection was done in 2007 (IFLS-4) with baseline is a population of approximately 18 years of age who then had the same individual take back data collection in 2014 (IFLS-5). The process of data collection in the same cohort for 7 years was the strength in the design of this study. However, this research is inseparable from the shortcomings and limitations.

Some considerations using this data because the research was conducted throughout Indonesia in the hope of representing the population in Indonesia aged $\geq 18$ years with the aim to determine the risk of hypertension against the risk of coronary heart disease in urban communities and in Indonesia. The weakness of using this data is that the variables studied must adjust to the 
available IFLS data, where other variables that are risk factors that might affect the research outcome cannot be examined.

The cumulative incidence of coronary heart disease in hypertension among urban communities in this study $(1.78 \%)$ is higher when compared with rural communities $(1.60 \%)$. Based on the results of the Basic Health Research in 2018, where the prevalence of coronary heart disease in urban communities $(1.60 \%)$ is higher when compared with rural communities $(1.30 \%){ }^{5}$ This shows that the IFLS data used can adequately describe the coronary heart disease population in Indonesia is due to the approximately equal prevalence of coronary heart disease in urban and rural communities.

Increased blood pressure is a heavy burden on the heart, which causes hypertrophy in the left ventricle or myocardial infarction. High and persistent blood pressure will cause direct trauma to the walls of the coronary arteries, making coronary atherosclerosis easier. This causes angina pectoris. High blood pressure continuously causes damage to the arterial system of the arteries, with the artery slowly also caused by increased levels of cholesterol in the blood, this process constricts the lumen in the blood vessels so that blood flow becomes blocked. ${ }^{18}$

We observed that the cumulative incidence of coronary heart disease in hypertension was higher in urban than in rural (Table 1). This occurred, probably because the distribution of CHD risk factor characteristics was more dominant in urban areas than in rural areas such as age, sex, education, obesity, smoking, and occupation are significantly higher in the urban population. While cholesterol history, DM history, and physical activity are more common in rural areas.

As in table 2 above shows the analysis of stratification relationship hypertension with CHD in urban and rural areas based on risk factor categories, it can be seen that the category of CHD risk factors is more dominated in urban areas such as age, sex, education, physical activity, DM history, occupation significantly higher in urban populations, while obesity and a history of cholesterol are more common in rural areas. The final model of multivariate analysis (Table 3) show hypertension in urban communities were at 1.36 times more risk $(95 \% \mathrm{CI} ; 1.05-1.77)$ had coronary heart disease compared to respondents who were not hypertensive/normal. While in rural communities, there was no significant relationship between hypertension and CHD with RR values of 1.07 (95\% CI = 0.78-1.48).

The results of a study conducted by Biswas, Singh, \& Singh., stated that in India, the prevalence of coronary heart disease in urban communities $(1.4 \%)$ was higher than in rural communities $(0.8 \%)$ in 2011-2012. In his research also showed that after the OR was adjusted for socioeconomic and demographic variables, hypertension was found to be five times more likely $(\mathrm{OR}=5.09, \mathrm{P}<0.01)$ for the occurrence of coronary heart disease compared with no hypertension. ${ }^{8}$ 
Multivariate logistic regression analysis study identified an increase in age, a history of hypertensive parents, smoking, chewing tobacco, physical activity, a high estimate of salt consumption per capita, and a BMI $\geq 27.5 \mathrm{~kg} / \mathrm{m} 2$ as an independent predictor for hypertension in urban populations, while in rural populations, increasing age, physical activity, central obesity, chewing tobacco and smoking are independent predictors of hypertension. ${ }^{12}$

Research conducted by Zeidan et al. , that the prevalence among urban men is $7.30 \%$ (95\% $\mathrm{CI}=5.70-8.90)$ and $13.40 \%(95 \% \mathrm{CI}=\mathrm{s} 11.20-15.60)$ among urban women is higher than the prevalence of coronary heart disease among men rural men, namely $3.40 \%(95 \% \mathrm{CI}=1.60-5.20)$ and $7.40 \%(95 \% \mathrm{CI}=4.70-10.10)$ among rural women. The results of the binary logistic regression analysis found that after adjusted OR value of $1.26(95 \% \mathrm{CI}=0.96-1.65)$ means that hypertension is at risk of 1.26 times having coronary heart disease compared with no hypertension/normal. ${ }^{19}$

Research conducted by Bodkhe et al., which conducted a community-based cross-sectional study of the epidemiology of coronary heart disease confirmed among populations over 60 years in rural central India, found that hypertension was found to be the only independent risk factor for coronary heart disease, in the results of bivariate and regression analyzes logistic (after adjusted OR value of 7.07 (95\% CI $=3.28-15.25)$ means that respondents who have hypertension are at risk of 7.07 times having coronary heart disease compared with respondents who are not hypertensive. ${ }^{20}$

Case-control research conducted by Amisi et al shows that hypertension is associated with the occurrence of CHD where respondents who suffer from hypertension are more at risk of 2.67 times suffering from CHD than those who do not suffer from hypertension. ${ }^{21}$ As for research conducted by Dwi, Ferry, \& Irwan., stated that there was a relationship between hypertension duration with CHD $(p=0.028)$ and hypertension duration 11-15 years at 2.96 times the risk of CHD compared to hypertension duration 1-10 years. There is a long-standing effect of hypertension on CHD, the longer hypertension, the higher the risk of CHD. ${ }^{22}$ In a prospective cohort study conducted by Huang et al that pre-hypertension increases the risk of 1.43 times for coronary heart disease (RR $1.43 ; 95 \% \mathrm{CI}=1.15-1.61) .{ }^{10}$

The prevalence of CHD in Kerala has increased over the past two decades, largely supported by coronary risk factors. There is a high prevalence of CHD among young individuals (2\%) compared to western data $(1.2 \%)$. Contrary to most of the previous Indian data, there was no difference between the prevalence of urban (15.1\%) and rural CAD (16.2\%) in this study. ${ }^{23} \mathrm{~A}$ cross-sectional study showed that in rural communities suffering from hypertension as much as $43.8 \%$ while in urban communities suffering from hypertension as much as $46.2 \%$, there was no difference between the prevalence between urban and rural areas with a p-value $=0.874 .{ }^{24}$

Research results from 22,093 participants, 6,455 (29.2\%) had a high cardiovascular risk, defined as the presence of coronary heart disease, stroke or other atherosclerotic diseases; Estimated ten years 30\% CVD risk, or an estimated 10-year CVD risk of between $10 \%$ and $29 \%$ 
combined with a systolic blood pressure $>140 \mathrm{mmHg}$. The high CVD risk prevalence is greater at urban $(31.6 \%$, CI $30.7-32.5 \%)$ than in semi-urban $(28.7 \%$, CI $27.3-30.1 \%)$ and rural areas $(26.2 \%$, CI $25.2-27.2 \%){ }^{25}$ The quality of the data in this study is largely determined by data collection officers or enumerators in the field in controlling selection bias and information bias. There is missing data that requires data to be dropped out so that it will lose exposure and outcome which also means the loss of research respondents (samples). The strength of the physical examination of some of the variables used in this study was carried out by competent health workers such as doctors, nurses or midwives, however, measuring instruments used such as blood pressure measuring devices cannot be ascertained because the blood pressure measuring device used is a digital tensimeter. so that the results will tend to be more than they should be, but even though this happens it will apply equally to both groups, both the exposed group and the non-exposed group, the measurement is carried out through interviews where the answer comes from the respondent's honesty or the respondent does not understand the questions asked such as the activity variable physical.

\section{Conclusion}

Respondents with hypertension in urban communities were at 1.36 times more risk $(95 \% \mathrm{CI}$; 1.05-1.77) had coronary heart disease compared to respondents who were not hypertensive/normal in Indonesia 2007-2014. Whereas in rural communities, there was no significant relationship between hypertension and CHD with RR values of 1.07 (95\% CI $=0.78-1.48)$.

\section{Acknowledgment}

The author would like to thank for all who helped in this research.

\section{Funding:}

There is no funding for research.

\section{Conflict of Interest:}

The authors declare that they have no conflict of interest.

\section{Reference}

1. Gaziano TA, Bitton A, Anand S, Abrahams-Gessel S, Murphy A. Growing Epidemic of Coronary Heart Disease in Low- and Middle-Income Countries. Curr Probl Cardiol. 2010;35(2):72-115.

2. Darjoko ST. High carbohydrate intake increases risk of coronary heart disease in adults: a 
prospective cohort study [Internet]. 2017 [cited 2020 Jun 14]. Available from: https://www.who.int/news-room/fact-sheets/detail/cardiovascular-diseases-(cvds)

3. Darjoko ST, Wahyuningsih T, Sudikno S. High carbohydrate intake increases risk of coronary heart disease in adults: a prospective cohort study. Universa Med. 2019;38(2):90.

4. Pradono J, Asri Werdhasari dan, Upaya Kesehatan Masyarakat Balitbangkes P, Biomedis dan Teknologi Dasar Kesehatan Balitbangkes P. Faktor Determinan Penyakit Jantung Koroner pada Kelompok Umur 25-65 tahun di Kota Bogor, Data Kohor 2011-2012 determinant factors of coronary heart disease at age 25-65 years in bogor city, kohort study. 2011;0-1. Available from: http://dx.doi.org/10.22435/bpk.v46i1.7326.23-34

5. Kementerian Kesehatan RI Badan Penelitian dan Pengembangan. Hasil Utama Riset Kesehatan Dasar. Kementrian Kesehat Republik Indones [Internet]. 2018;1-100. Available from: http://www.depkes.go.id/resources/download/info-terkini/hasil-riskesdas-2018.pdf

6. Kemenkes RI. Situasi kesehatan jantung. Pus data dan Inf Kementeri Kesehat RI [Internet]. $2014 ; 3$. Available from: http://www.depkes.go.id/download.php?file=download/pusdatin/infodatin/infodatinjantung.pdf

7. Tempo.co. Orang Kota Lebih Rentan Kena Penyakit Jantung? Intip Solusinya. Sabtu, 29 September 2018 19:30 WIB [Internet]. 2018 Sep; Available from: https:/gaya.tempo.co/read/1131334/orang-kota-lebih-rentan-kena-penyakit-jantung-intipsolusinya

8. Biswas Ayantika, Shri Kant Singh RKS. Linkages between hypertension and coronary heart disease in India: Evidence from India human development survey-2 (2011-2012). Indian J Community Med [Internet]. 2017;42(4):200--203. Available from: http://www.ijcm.org.in/printarticle.asp?issn=09700218; year $=2017$; volume $=42$;issue $=4$; spage $=200$; epage $=203$; aulast $=$ Biswas

9. Singh Shikha, Ravi Shankar and GPS. Prevalence and Associated Risk Factors of Hypertension: A Cross-Sectional Study in Urban Varanasi. Int J Hypertens [Internet]. 2017;2017:10. Available from: https://www.hindawi.com/journals/ijhy/2017/5491838/

10. Huang Y, Cai X, Liu C, Zhu D, Hua J, Hu Y, et al. Prehypertension and the risk of coronary heart disease in Asian and Western populations: a meta-analysis. J Am Heart Assoc. 2015;4(2):1-11.

11. Kavi A, Walvekar PR PR. Biological risk factors for coronary artery disease among adults residing in rural area of North Karnataka, India. J Fam Med Prim Care [Internet]. 2019;8(1):148-53. Available from: http://www.jfmpc.com/text.asp?2019/8/1/148/251158

12. Bhadoria A, Bhadoria P, Kabirpanthi V, Kasar P, Pradhan S, Toppo N. Prevalence of hypertension and associated cardiovascular risk factors in Central India. J Fam Community 
Med. 2014;21(1):29.

13. Li J, Shi L, Li S, Xu L, Qin W, Wang H. Urban-rural disparities in hypertension prevalence, detection, and medication use among Chinese Adults from 1993 to 2011. Int J Equity Health. 2017;16(1):1-10.

14. Yang G, Ma Y, Wang S, Su Y, Rao W, Fu Y, et al. Prevalence and correlates of prehypertension and hypertension among adults in northeastern China: A cross-sectional study. Int J Environ Res Public Health. 2015;13(1):1-12.

15. RAND Corporation. The Indonesia Family Life Survey (IFLS) [Internet]. 2014. Available from: https://www.rand.org/well-being/social-and-behavioral-policy/data/FLS/IFLS.html

16. Chobanian A V., Bakris GL, Black HR, Cushman WC, Green LA, Izzo JL, et al. The Seventh Report of the Joint National Committee on Prevention, Detection, Evaluation, and Treatment of High Blood Pressure: The JNC 7 Report. J Am Med Assoc. 2003;289(19):2560-72.

17. Kemenkes RI. Klasifikasi Hipertensi [Internet]. 12 Mei 2018. 2018 [cited 2020 Jul 29]. Available from: http://www.p2ptm.kemkes.go.id/infographic-p2ptm/hipertensi-penyakitjantung-dan-pembuluh-darah/klasifikasi-hipertensi

18. Defriman Djafri1, Monalisa1, Fauziah Elytha1 RM. Efek modifikasi faktor risiko modifiable penyakit jantung koroner: a hospital-based matched case control study. J Kesehat Masy Andalas. 2017;11(2):93-9.

19. Zeidan RK, Farah R, Chahine MN, Asmar R, Hosseini H. Prevalence and correlates of coronary heart disease : first population-based study in Lebanon. 2016;75-85.

20. Bodkhe S, Jajoo SU, Jajoo UN, Ingle S, Gupta SS, Taksande BA. Epidemiology of confirmed coronary heart disease among population older than 60 years in rural central India-A community-based cross-sectional study. Indian Heart J [Internet]. 2019;71(1):39-44. Available from: https://doi.org/10.1016/j.ihj.2019.01.002

21. Amisi WG, Nelwan JE, Kolibu FK. Hubungan Antara Hipertensi Dengan Kejadian Penyakit Jantung Koroner Pada Pasien Yang Berobat Di Rumah Sakit Umum Pusat Prof. Dr. R. D. Kandou Manado. J Kesmas [Internet]. 2018;7(4):1-7. Available from: https://ejournal.unsrat.ac.id/index.php/kesmas/article/download/23124/22819

22. Novriyanti ID, Usnizar F, Irwan. Pengaruh Lama Hipertensi Terhadap Penyakit Jantung Koroner di Poliklinik Kardiologi RSUP. Dr. Mohammad Hoesin Palembang 2012. J Kedokt dan Kesehat. 2014;1(1):55-60.

23. Krishnan MN. Coronary heart disease and risk factors in India - On the brink of an epidemic? Indian Heart J [Internet]. 2012;64(4):364-7. Available from: http://dx.doi.org/10.1016/j.ihj.2012.07.001

24. Nabila MF. Perbedaan Kejadian Hipertensi Pada Masyarakat Rural-Urban di Kabupaten 
Bogor 2014 [Internet]. Universitas Islam Negeri Syarif Hidayatullah Jakarta; 2014. Available from: http://repository.uinjkt.ac.id/dspace/bitstream/123456789/33015/1/Mayli Faroh NabilaFKIK.pdf

25. Maharani A, Sujarwoto, Praveen D, Oceandy D, Tampubolon G, Patel A. Cardiovascular disease risk factor prevalence and estimated 10-year cardiovascular risk scores in Indonesia: The SMARThealth Extend study. PLoS One. 2019;14(4):1-13. 